\title{
Communications
}

Examen de spécialiste

Examen de spécialiste en vue de l'obtention du titre de spécialiste en dermatologie et vénéréologie

Examen écrit SSDV

Date:

13 novembre 2021

Lieu:

Berne (lieu exact à préciser)

Délai d'inscription:

L'inscription à l'examen écrit commence

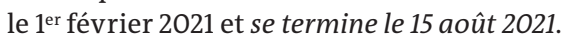

Examen oral SSDV

Date:

25 novembre 2021

Lieu:

Hôpital universitaire de Zurich

Délai d'inscription:

L'inscription à l'examen oral commence le $1^{\text {er }}$ février 2021 et se termine le 15 août 2021.

Vous trouverez de plus amples informations sur le site web de l'ISFM www.siwf.ch $\rightarrow$ formation postgraduée $\rightarrow$ Titres de spécialiste et formations approfondies $\rightarrow$ dermatologie et vénéréologie

\section{Jack Plaschkes Memorial Award}

The Swiss Paediatric Oncology Group (SPOG) and the Swiss Society of Pediatric Surgery are delighted to open applications for the JACK PLASCHKES Memorial Award 2020/2021 in the amount of CHF 5000.

This prize is intended to promote Clinical and/or Basic Research in the field of Paediatric Oncological Surgery in Switzerland.

We encourage junior colleagues fulfilling the requirements to apply.

Requirements for applicants:

- Paediatric surgeons in training

- Age below 40 years (i.e. born after 1.1.1980)

- Swiss candidate working in a Swiss or foreign academic institution

- Swiss candidate or foreigner working in a Swiss academic institution

- Foreigners working outside Switzerland in collaboration with a Swiss academic institution
Clinical Research or Basic science Projects which are achieved, in process or in project, can be submitted.

Please send the following documents:

- Up-to-date CV

- Cover letter

- Letter of recommendation from a supervisor

- Short summary (max. 4,000 characters) describing the project

to:

Partner Relations partnerrelations[at]spog.ch SPOG Coordinating Center Effingerstrasse 33, 3008 Bern

before 15 April 2021.

The selected candidate will be awarded during the SPOG Scientific Meeting (4-5 June 2021) in Bern.

\section{Sujets d'actualité en ligne}

www.bullmed.ch $\rightarrow$ Tour d'horizon
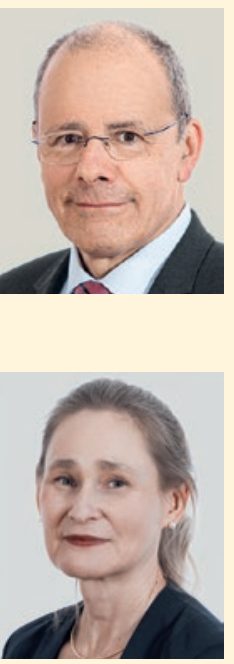

Entretien avec Jürg Schlup, le président sortant de la FMH

\section{«Se mettre en avant n'apporte rien»}

En 2012, Jürg Schlup a été élu à la tête de la Fédération des médecins suisses. Fin janvier, il passe les rênes à sa successeure Yvonne Gilli. Il est temps pour lui de revenir sur huit années mouvementées.

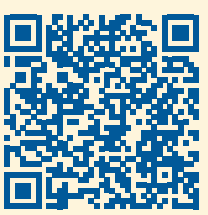

Ursina Pally Hofmann, avocate, Secrétaire générale et cheffe du Service juridique de la FMH

\section{Vaccin contre le COVID-19: responsabilités et droits des patients}

Réponses aux principales questions liées à la responsabilité civile et aux obligations des médecins en matière de vaccination.

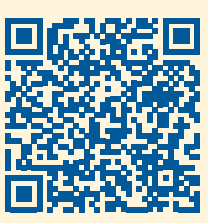

